Article

\title{
Development of Building Information Modeling Template for Environmental Impact Assessment
}

\author{
Sungwoo Lee ${ }^{1}$, Sungho Tae ${ }^{2, *}$, Hyungjae Jang ${ }^{2, *}$, Chang U. Chae ${ }^{3}$ and Youngjin Bok ${ }^{4}$ \\ 1 GHG Inventory Management Team, Greenhouse Gas Inventory and Research Center of Korea, \\ Seoul 03181, Korea; greennaver@gmail.com \\ 2 Department of Smart City Engineering, Hanyang University, Ansan 15644, Korea \\ 3 Korea Institute of Civil Engineering and Building Technology, Goyang 10454, Korea; cuchae@kict.re.kr \\ 4 GHG Reduction Team, Greenhouse Gas Inventory and Research Center of Korea, Seoul 03181, Korea; \\ bokyoungiin@korea.kr \\ * Correspondence: jnb55@hanyang.ac.kr (S.T.); duethj@gmail.com (H.J.); \\ Tel.: +82-31-400-5187 (S.T.); Fax: +82-31-406-711 (S.T. \& H.J.)
}

Citation: Lee, S.; Tae, S.; Jang, H.; Chae, C.U.; Bok, Y. Development of Building Information Modeling Template for Environmental Impact Assessment. Sustainability 2021, 13, 3092. https://doi.org/10.3390/ su13063092

Academic Editor:

Antonio Garcia-Martinez

Received: 23 January 2021

Accepted: 2 March 2021

Published: 11 March 2021

Publisher's Note: MDPI stays neutral with regard to jurisdictional claims in published maps and institutional affiliations.

Copyright: () 2021 by the authors. Licensee MDPI, Basel, Switzerland. This article is an open access article distributed under the terms and conditions of the Creative Commons Attribution (CC BY) license (https:// creativecommons.org/licenses/by/ $4.0 /)$.

\begin{abstract}
Eco-friendly building designs that use building information modeling (BIM) have become popular, and a variety of eco-friendly building assessment technologies that take advantage of BIM are being developed. However, existing building environmental performance assessment technologies that use BIM are linked to external assessment tools, and there exist compatibility issues among programs; it requires a considerable amount of time to address these problems, owing to the lack of experts who can operate the programs. This study aims to develop eco-friendly templates for assessing the embodied environmental impact of buildings using BIM authoring tools as part of the development of BIM-based building life cycle assessment (LCA) technologies. Therefore, an embodied environmental impact unit database was developed, for major building materials during production and operating stages, to perform embodied environmental impact assessments. Moreover, a major structural element library that uses the database was developed and a function was created to produce building environmental performance assessment results tables, making it possible to review the eco-friendliness of buildings. A case study analysis was performed to review the feasibility of the environmental performance assessment technologies. The results showed a less than $5 \%$ effective error rate in the assessment results that were obtained using the technology developed in this study compared with the assessment results based on the actual calculation and operating stage energy consumption figures, which proves the reliability of the proposed approach.
\end{abstract}

Keywords: building information modeling; building information modeling template; BIM library; life cycle assessment

\section{Introduction}

Global interest in environmental issues is increasing owing to severe environmental pollution worldwide. Thus, countries have been using the life cycle assessment (LCA) method proposed in the ISO 14000 series of international standards to perform environmental impact assessments across various fields of industry, while efforts are being made to reduce various kinds of environmental loads, including global warming [1]. In the construction industry, the LCA method is being introduced to assess the various environmental impacts caused by construction activities. Recently, to emphasize the importance of building environmental impact assessments, certification standards for LCAs were added to the 2016 Korean green building certification program (G-SEED), and the guidelines were revised and publicly announced [2]. A building LCA includes an assessment of the environmental impact of construction materials, regarded as the embodied environmental impact of the building. Internationally, research is being conducted to develop building 
LCA programs and to make it possible to easily assess the embodied environmental impact of building materials [3].

However, to use BIM-based building embodied environment impact assessment technology in a more practical way, the following improvements must be made. First, it is necessary to conduct embodied environmental impact assessments that use a life cycle inventory (LCI) database, which differentiates construction materials based on their physical properties such as strength. Even when concrete is of the same type, there may be differences in environmental impact units based on the strength of the concrete, which has a significant effect on the results of building embodied environment impact assessments [4]. Second, the LCA certification standards in the G-SEED program must consider various categories of environmental impacts caused by a building, not just for the global warming potential. Therefore, in addition to global warming, which has been the subject of many studies in the past, other environmental impacts, including resource depletion potential [5] must be considered. Third, it is necessary to consider BIM-based studies that examine environmental cost assessments. Currently, various types of environmental impacts are being considered in terms of their indirect social costs so that they can be examined in monetary terms, known as the environmental cost, and the significance of this cost is increasing. Fourth, the environmental impact of energy consumption during the operation stage, which accounts for more than $60 \%$ of energy consumption during a building's entire lifespan, must be considered, starting from the design stage [6].

Therefore, the goal of this study is to create a BIM template with environmental impact parameters (BTEI), which can assess six categories of environmental impacts and environmental costs caused by specific building materials, as well as the design stage environmental impacts, to improve the accuracy of BIM-based building embodied environmental impact assessments.

To achieve this, environmental impact categories and environmental costs were defined. Six environmental impacts and environmental cost units were created for major building elements, and libraries were created for assessing the six environmental impacts as well as environmental costs. The libraries can be used in the BIM authoring tool Revit, and they consist of 3D objects with associated technical data. Revit allows for additional parameters to be created and applied to the libraries, and the data can be processed by inserting formulas for parameters and calculating the results.

This study used Autodesk Revit Architecture 2015 to model major structural elements, and it included database information that allows the environmental impact of building materials to be assessed.

KS I ISO 14025 presents a list of various environmental impact types that affect the global environment [7-9]. The environmental product declaration (EPD) certification system, which is operated by the Korean Ministry of Environment, assesses six categories of environmental impacts, including global warming (GWP), abiotic depletion (ADP), acidification potential (AP) eutrophication (EP), ozone layer depletion (ODP), and photochemical oxidation (POCP) [10]. The Korean Ministry of Environment has developed and released the LCI database in which substances that have an impact by categories are listed by product and material, and the Ministry distributes an LCA program to assess the environmental performance of products [11].

The LCI database can be calculated to develop environmental impact units based on the environmental impact categories using classification and characterization stages for each substance. These units can then be multiplied by a quantity based on the product's unit to calculate an environmental impact value.

This study used a library to develop a database for assessing the operating stage environmental impact of buildings, based on the designed building's total floor area.

Figure 1 shows the development method and assessment scope of the BTEI system proposed in this study. A template can be defined as an environment in which building environmental assessments can be performed autonomously in the BIM authoring tool without connecting to external assessment software. This study was performed using 
the Autodesk Revit Architecture 2015. To confirm the significance of this study, the environmental impact assessment results produced using the BIM library, considering the proposed environmental impact parameters, were compared with those based on actual calculation results and energy consumption.
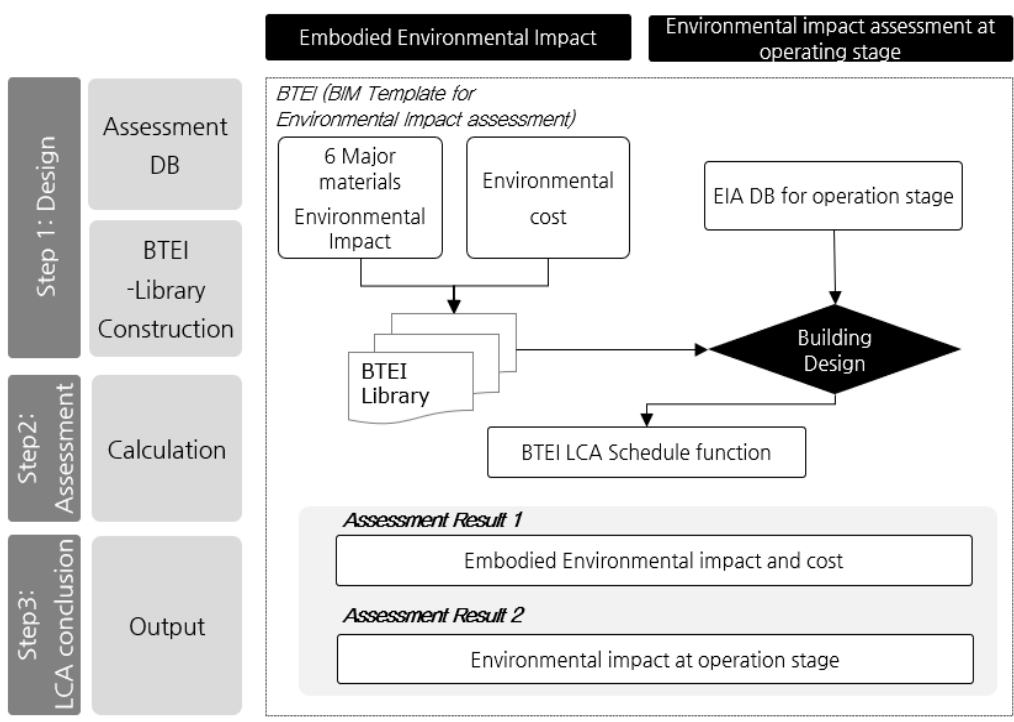

Figure 1. Development and scope of building information modeling (BIM) template with environmental impact parameters (BTEI).

\section{BTEI Library Construction}

\subsection{Overview}

The environmental impact assessment library created in this study is a BIM library that includes the environmental impact and environmental cost unit parameter data for major construction materials so that environmental impact and environmental cost assessments can be performed automatically for each material based on calculations [12]. In this study major construction materials were selected by considering the results of previous studies, and subdivided by the environmental information of materials to increase the library's accuracy [13]. The selected materials were used for library modeling. In addition, the national LCI database and the results of previous studies were used to analyze environmental impact and environmental cost units These database were recreated within the library as parameters to develop the library.

\subsection{Selecting Major Construction Materials and Elements}

Major construction materials were selected by considering the materials that cause environmental load among building construction materials, along with the construction material information that was calculated at a level of detail (LOD) of 300, which is the modeling standard suggested by the Korean Ministry of Land, Infrastructure, and Transport's BIM guidelines. By referring to previous studies that analyzed materials accounting for $95 \%$ of the environmental impact of materials used in buildings, concrete, rebar, steel framing, glass, insulation, gypsum board, and concrete products were initially selected in this study [14].

However, instead of concrete products, bricks were selected as an assessment target, as they are predominantly used in the construction industry in South Korea. However, rebar and steel framing were excluded as they were not a part of the LOD 300 standard; five major construction materials (concrete, glass, bricks, insulation, gypsum board, and concrete products) were selected [15].

In addition, the library was constructed with six structural elements (walls, columns, beams, slabs, windows, and foundations) as suggested by Korea's Ministry of Land, Infrastructure and Transport. 


\subsection{Calculating Environmental Impact Parameters}

To create environmental impact parameters in the assessment library, the LCI database entries for each construction material were analyzed, and environmental impact units and environmental cost units were calculated, as shown in Table 1 [16].

As observed in the ready-mixed concrete item in Table 2, different unit values were calculated for the same construction material depending on the specific type [17]. In the case of ready-mixed concrete, it was found that there were differences in the LCI database based on the ratio of cement and admixture. Because of this, there were differences in the environmental impact unit based on the strength of the ready-mixed concrete.

Parameters were created in the library that models these six environmental impact units and environmental cost units, and a BTEI library containing these environmental impact parameters was developed.

In the component library, elements were modeled as shown in Figure 2 and saved in separate files. Similarly, parameters were added via type characteristics and saved in the environmental impact assessment unit database. After the library was developed, it was linked to the assessment unit database, and the Revit Assessment table was set up to allow automatic calculations. Thus, it was possible to monitor the assessment results when users performed modeling using the BTEI library [18].

\subsection{Development of BIM Library That Considers Environmental Impact Parameters}

The BTEI library comprises six elements with five major construction materials, including 12 walls, 6 columns, 30 windows, 6 beams, 6 slabs, and 12 foundations. Of these, the window, column, and foundation elements are system libraries that were constructed as separate files, and the wall, slab, and beam elements are component libraries that were constructed within a task file.

The wall and slab libraries were constructed as single construction materials so that the user could model combined elements based on the project. In addition, owing to the variety of modern construction projects and the increasing height of apartment buildings, concrete of varying strength and various types of insulation, glass, etc. are used for each part of a building. Therefore, to facilitate environmental impact assessments that consider this variety, libraries were developed to account for the specific characteristics of materials, as shown in Table 2 [19].

Wall elements use major construction materials such as concrete, gypsum board, and insulation. Six concrete wall elements were created to take into account concrete of varying strength $(21,24,27,30,35$, and $40 \mathrm{MPa})$ [20].

Similarly, elements such as beams, slabs, and foundations, made of concrete, were created considering the six varying concrete strengths. Among the construction materials, concrete is a major emissions source of the GWP, and its environmental impact units are calculated differently owing to the difference in the LCI database for each concrete strength. Therefore, when assessing the embodied environmental impact of a building, the use of environmental impact units for each concrete strength improves the accuracy of the building LCA results. Consequently, in the BIM-based LCAs using the BTEI library created in this study, the accuracy of the assessment results can be improved by using environmental impact units for each concrete strength [21].

In the case of the BTEI-library-wall items, an LCI database with three different types of insulation (glass wool, expanded polystyrene, and extruded polystyrene) was used to create three insulation walls. LCI database entries for concrete bricks and clay bricks were used to create two wall-brick items. Similarly, LCI database entries for three types of glass (plate, double glazing, and tempered) were used for each of 10 basic windows, such as four-unit sliding windows, single swinging windows, and fixed windows, to create 30 window libraries [22]. 
Table 1. Database for evaluating environmental impact parameters.

\begin{tabular}{|c|c|c|c|c|c|c|c|c|c|}
\hline \multirow{2}{*}{$\begin{array}{l}\text { Major. } \\
\text { Materials }\end{array}$} & \multirow[b]{2}{*}{ Subdivision } & \multirow[b]{2}{*}{ Unit } & \multicolumn{6}{|c|}{6 Environmental Impact Database } & \multirow{2}{*}{$\begin{array}{c}\text { Environmental } \\
\text { Cost } \\
\text { (Won) }\end{array}$} \\
\hline & & & $\begin{array}{c}\mathrm{GWP} \\
{\left[\mathrm{kg}-\mathrm{CO}_{2} \text { eq/Unit }\right]}\end{array}$ & $\begin{array}{c}\text { ADP } \\
\text { [kg/Unit] }\end{array}$ & $\begin{array}{c}\mathrm{AP} \\
{\left[\mathrm{kg}-\mathrm{SO}_{2} \mathrm{eq} / \text { Unit }\right]}\end{array}$ & $\begin{array}{c}\mathrm{EP} \\
{\left[\mathrm{kg}-\mathrm{PO}_{4}{ }^{3-} \text { eq/Unit }\right]}\end{array}$ & $\begin{array}{c}\text { ODP } \\
\text { [kg-CFC-11eq/Unit] }\end{array}$ & $\begin{array}{c}\text { POCP } \\
\text { [kg-Ethyleneeq/Unit] }\end{array}$ & \\
\hline \multirow{2}{*}{$\begin{array}{l}\text { Ready-mixed } \\
\text { Concrete }\end{array}$} & $21 \mathrm{MPa}$ & $\mathrm{m}^{3}$ & $4.19 \times 10^{2}$ & $1.56 \times 10^{0}$ & $6.94 \times 10^{-1}$ & $8.08 \times 10^{-2}$ & $4.61 \times 10^{-5}$ & $1.13 \times 10^{0}$ & $1.53 \times 10^{4}$ \\
\hline & $24 \mathrm{MPa}$ & $\mathrm{m}^{3}$ & $4.29 \times 10^{2}$ & $2.08 \times 10^{0}$ & $7.05 \times 10^{-1}$ & $8.20 \times 10^{-2}$ & $4.59 \times 10^{-5}$ & $1.15 \times 10^{0}$ & $1.56 \times 10^{4}$ \\
\hline Glass & Plate Glass & Ton & $7.88 \times 10^{2}$ & $6.97 \times 10^{0}$ & $3.67 \times 10^{0}$ & $5.23 \times 10^{-2}$ & $3.04 \times 10^{-4}$ & $8.95 \times 10^{-1}$ & $5.60 \times 10^{4}$ \\
\hline Brick & Concrete Brick & $1000 \mathrm{EA}$ & $1.23 \times 10^{-1}$ & $1.46 \times 10^{-4}$ & $1.57 \times 10^{-4}$ & $2.27 \times 10^{-5}$ & $4.71 \times 10^{-9}$ & $1.31 \times 10^{-5}$ & $2.90 \times 10^{0}$ \\
\hline Insulation & Glass Wool & $\mathrm{Kg}$ & $1.05 \times 10^{0}$ & $5.06 \times 10^{-1}$ & $1.83 \times 10^{1}$ & $4.95 \times 10^{-1}$ & $5.02 \times 10^{-1}$ & $7.39 \times 10^{-4}$ & $2.68 \times 10^{5}$ \\
\hline Gypsum Board & - & Ton & $1.92 \times 10^{-1}$ & $1.55 \times 10^{-2}$ & $3.13 \times 10^{-2}$ & $5.28 \times 10^{-3}$ & $5.67 \times 10^{-7}$ & $7.61 \times 10^{-3}$ & $4.47 \times 10^{2}$ \\
\hline
\end{tabular}

GWP: Global warming; ADP: Abiotic depletion; AP: Acidification potential; EP: Eutrophi-cation; ODP: Ozone layer depletion; POCP: Photochemical oxidation. 


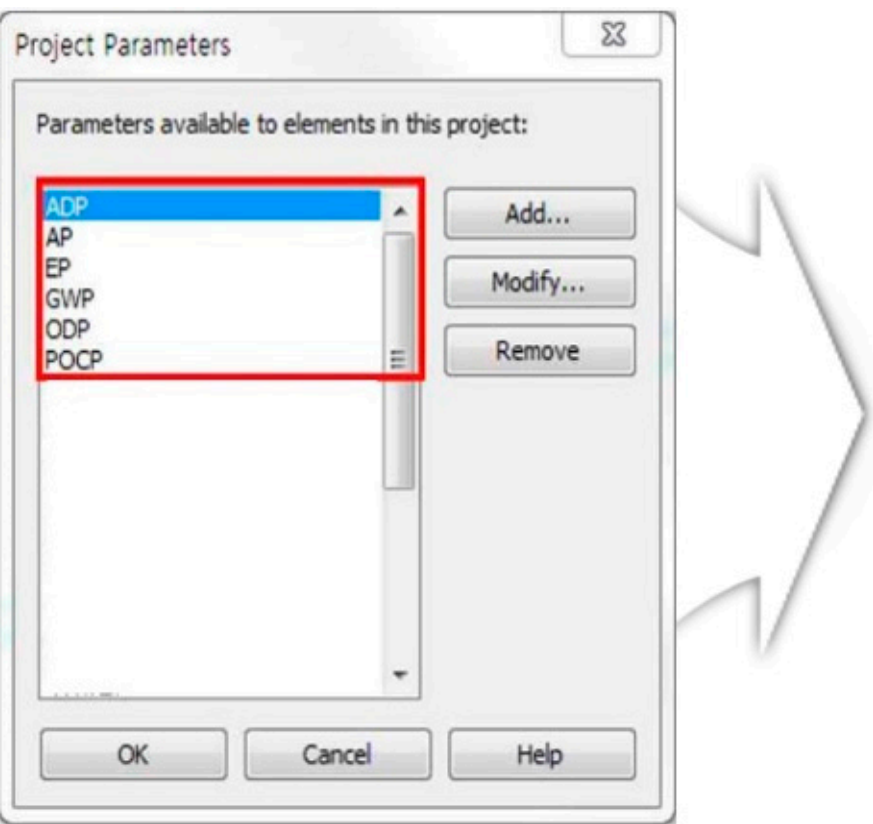

(a) Parameter creation

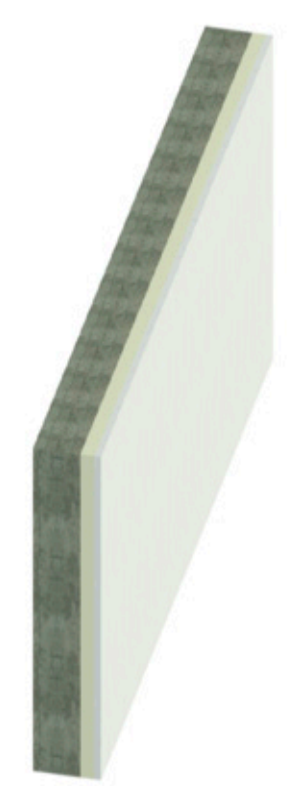

(b) Library design Wall library item creation]

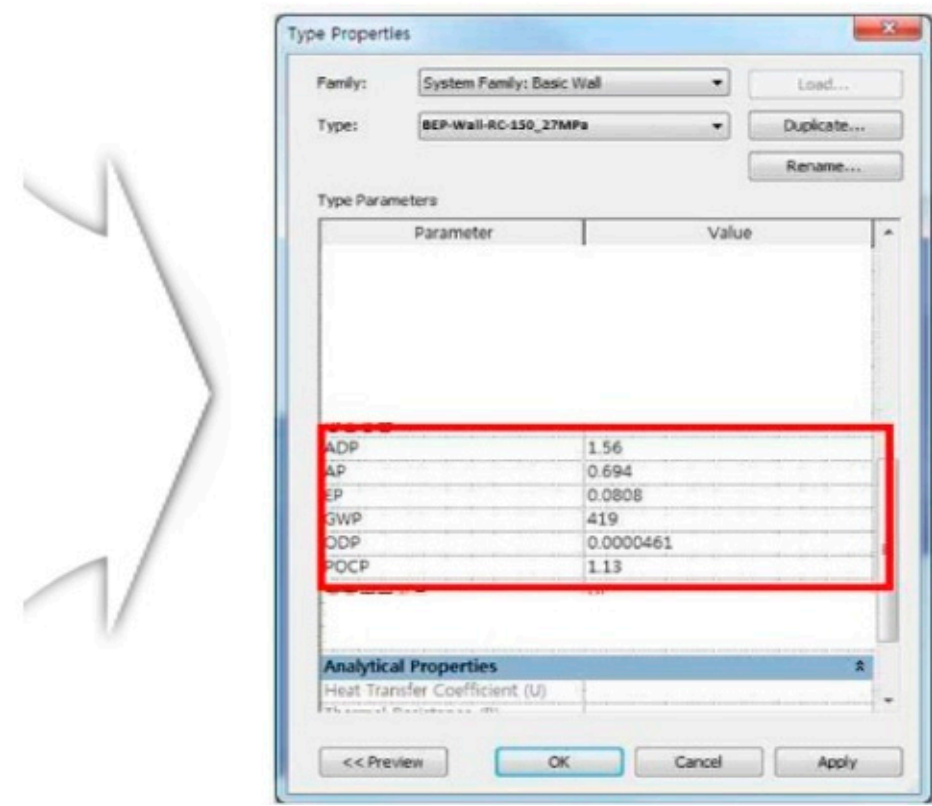

(c) DB input

Figure 2. Cont. 


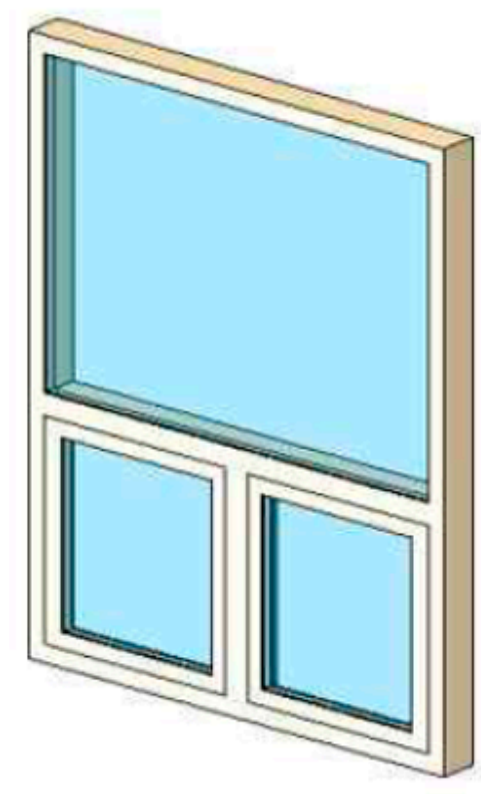

(d) Parameter creation

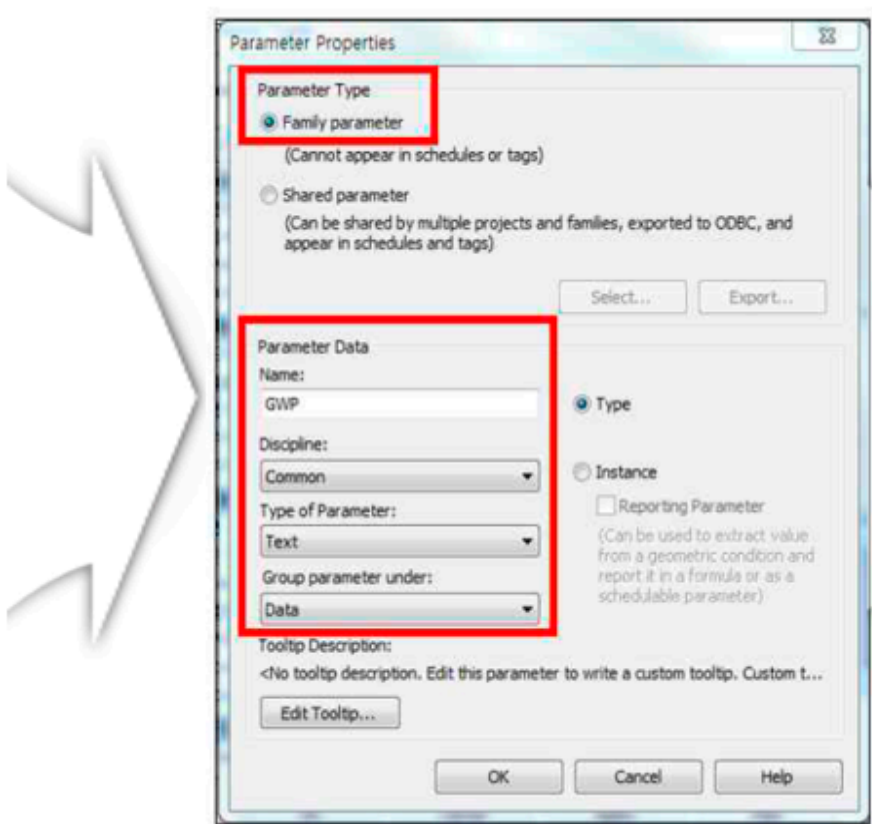

(e) Library design

[Window library item creation]

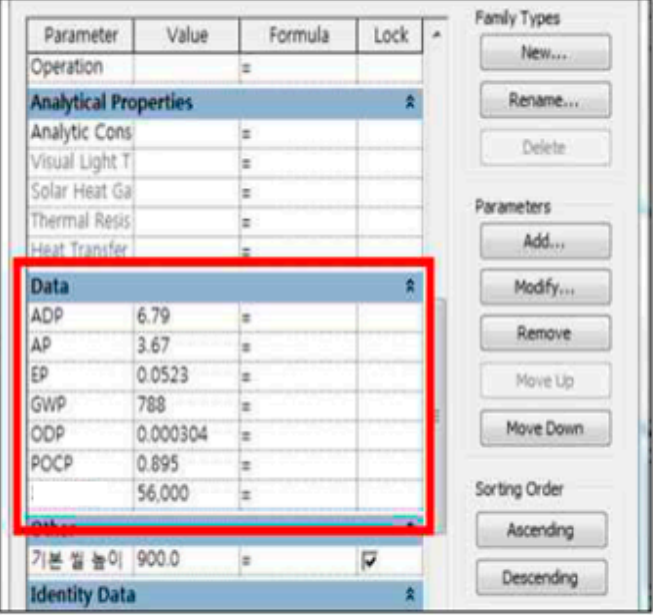

(f) DB input

Figure 2. BTEI-library development method. 
Table 2. Subdivision in materials of each elements.

\begin{tabular}{cccc}
\hline \multirow{2}{*}{ Elements } & Material & Subdivision & File Format \\
\cline { 2 - 4 } & $\begin{array}{c}\text { Ready-mixed } \\
\text { concrete }\end{array}$ & Strength & Inplace Library \\
\cline { 2 - 4 } & Insulation & Type & Inplace Library \\
\cline { 2 - 4 } & Brick & Type & Inplace Library \\
\hline Slab & $\begin{array}{c}\text { Ready-mixed } \\
\text { concrete }\end{array}$ & Strength & Inplace Library \\
\hline Beam & $\begin{array}{c}\text { Ready-mixed } \\
\text { concrete } \\
\text { Window }\end{array}$ & Strength & Inplace Library \\
\hline Column & $\begin{array}{c}\text { Ready-mixed } \\
\text { concrete }\end{array}$ & Type & System Library \\
\hline Foundation & $\begin{array}{c}\text { Ready-mixed } \\
\text { concrete }\end{array}$ & Strength & System Library \\
\hline
\end{tabular}

The environmental impact and environmental cost assessment results were found for three environmental impact types (GWP, AP, and ODP) of several libraries of given sizes (BTEI-library-wall $200 \mathrm{~mm}$, BTEI-library-column $300 \times 300 \times 2700 \mathrm{~mm}^{3}$, BTEI-slab $150 \mathrm{~mm}$, BTEI-window-single-swinging) among the libraries that were created, by subdividing the building materials, as shown in Table 3.

Table 3. BTEI-library construction example.

\begin{tabular}{|c|c|c|c|c|c|}
\hline \multirow[b]{2}{*}{ Elements } & \multirow[b]{2}{*}{ Library Name } & \multicolumn{3}{|c|}{ Subdivision } & \multirow{2}{*}{$\begin{array}{l}\text { Environmental } \\
\text { Cost (won) }\end{array}$} \\
\hline & & $\begin{array}{c}\text { GWP } \\
{\left[\mathrm{kgCO}_{2} \mathrm{eq} / \text { Unit }\right]}\end{array}$ & $\begin{array}{c}\mathrm{AP} \\
{\left[\mathrm{kgSO}_{2} \mathrm{eq} / \text { Unit }\right]}\end{array}$ & $\begin{array}{c}\text { ODP } \\
{[\text { kg-CFC-11eq/Unit] }}\end{array}$ & \\
\hline & BTEI-Wall-RC_21MPa & $8.38 \times 10^{0}$ & $1.39 \times 10^{-2}$ & $9.22 \times 10^{-7}$ & $3.07 \times 10^{2}$ \\
\hline & BTEI-Wall-RC_24MPa & $8.58 \times 10^{0}$ & $1.41 \times 10^{-2}$ & $9.18 \times 10^{-7}$ & $3.12 \times 10^{2}$ \\
\hline $\begin{array}{l}\text { Wall-RC } \\
6 \text { species }\end{array}$ & BTEI-Wall-RC_27MPa & $4.79 \times 10^{0}$ & $7.42 \times 10^{-4}$ & $5.27 \times 10^{-6}$ & $8.05 \times 10^{1}$ \\
\hline & BTEI-Column-RC_21MPa & $4.53 \times 10^{2}$ & $7.50 \times 10^{-1}$ & $4.98 \times 10^{-5}$ & $1.66 \times 10^{4}$ \\
\hline & BTEI-Column-RC_24MPa & $4.63 \times 10^{2}$ & $7.61 \times 10^{-1}$ & $4.96 \times 10^{-5}$ & $1.69 \times 10^{4}$ \\
\hline $\begin{array}{l}\text { Column-RC } 6 \\
\text { species }\end{array}$ & BTEI-Column-RC_27MPa & $2.59 \times 10^{2}$ & $4.01 \times 10^{-1}$ & $2.85 \times 10^{-4}$ & $9.07 \times 10^{3}$ \\
\hline \multirow{3}{*}{$\begin{array}{l}\text { Slab-RC } \\
6 \text { species }\end{array}$} & BTEI-Slab-RC_21MPa & $6.29 \times 10^{0}$ & $1.04 \times 10^{-2}$ & $6.92 \times 10^{-7}$ & $2.30 \times 10^{2}$ \\
\hline & BTEI-Slab-RC_24MPa & $6.44 \times 10^{0}$ & $1.06 \times 10^{-2}$ & $6.89 \times 10^{-7}$ & $2.34 \times 10^{2}$ \\
\hline & BTEI-Slab-RC_27MPa & $3.60 \times 10^{0}$ & $5.57 \times 10^{-4}$ & $3.95 \times 10^{-6}$ & $6.04 \times 10^{1}$ \\
\hline \multirow{3}{*}{$\begin{array}{l}\text { Window } \\
30 \text { species }\end{array}$} & $\begin{array}{l}\text { BTEI-Window-Single } \\
\text { Swing-Plate Glass }\end{array}$ & $7.88 \times 10^{2}$ & $3.67 \times 10^{0}$ & $3.04 \times 10^{-4}$ & $5.60 \times 10^{4}$ \\
\hline & $\begin{array}{l}\text { BTEI-Window-Single } \\
\text { Swing-Double Glazing }\end{array}$ & $2.24 \times 10^{2}$ & $3.05 \times 10^{-1}$ & $1.81 \times 10^{-6}$ & $7.09 \times 10^{3}$ \\
\hline & $\begin{array}{l}\text { BTEI-Window-Single } \\
\text { Swing-Tempered Glass }\end{array}$ & $1.34 \times 10^{2}$ & $2.57 \times 10^{-1}$ & $6.64 \times 10^{-7}$ & $4.74 \times 10^{3}$ \\
\hline
\end{tabular}

In the case of the BTEI-Wall-RC-200 libraries, which are developed for concrete with the same thickness, the environmental impact and environmental cost values were calculated differently, based on strength. As mentioned before, there may be a difference in the environmental impact and environmental cost units according to the subdivided material information, even among libraries that are composed of the same construction material. 
Therefore, the results of assessments that use these libraries may also differ, as shown in Table 3.

Libraries were developed so that the users could set up elements of all sizes, and model the target elements by combining single material libraries. By doing so, modeling could be performed in response to a variety of construction projects, and environmental impact assessments could be performed on the materials used in buildings.

\section{Environmental Impact Assessments on the Operation Stage Using BTEI}

\subsection{Outline}

Generally, energy and maintenance costs have an important impact on decisionmaking during building planning and the basic design stage in LCAs. This study aims to create a system that can take into account the environmental impacts of the material production stage and operating stage energy consumption in building LCAs [23].

To achieve this, an environmental impact assessment database was developed in this study for each energy source used in a building. To consider the design stage energy consumption, 12 energy consumption databases for various building uses were provided to examine the operation stage environmental impact of buildings designed with the BTEI [24].

\subsection{Development of Environmental Impact Assessment Database for the Operation Stage}

The environmental impacts of operating stage energy sources occur during both the production stage and the combustion stage. Therefore, to calculate the environmental impact units of energy sources, the environmental impact of the energy source's production stage and combustion stage must be considered simultaneously, as shown in Equation (1). This study selected the national LCI database as the database for energy source production stages, and calculated the environmental impact units using the same method as the construction material (classification and specialization of the LCI database). However, the LCI database for the energy source production stage was not developed yet as a national LCI database, so the results of previous environmental impact analyses were used in this study. Table 4 shows the environmental impact units for the energy sources.

$$
E I C_{i, j}=\sum_{k}\left(P E_{i, k} \times I F_{j, k}+C E_{i, k} \times I F_{j, k}\right)
$$

Table 4. Database of environmental impact assessments by energy source.

\begin{tabular}{|c|c|c|c|c|c|c|c|c|}
\hline \multirow{2}{*}{$\begin{array}{l}\text { Energy } \\
\text { Source }\end{array}$} & \multirow{2}{*}{$\mathbf{F u}$} & \multirow{2}{*}{ Stage } & \multicolumn{6}{|c|}{ Environmental Impact Category } \\
\hline & & & GWP & AP & EP & ODP & POCP & ADP \\
\hline Electricity & $\mathrm{kWh}$ & Total & $4.88 \times 10^{-1}$ & $8.37 \times 10^{-4}$ & $1.56 \times 10^{-4}$ & $1.37 \times 10^{-11}$ & $1.41 \times 10^{-6}$ & $8.58 \times 10^{-4}$ \\
\hline \multirow{3}{*}{ Heat } & \multirow{3}{*}{ Gcal } & Production & $3.20 \times 10^{-1}$ & $2.96 \times 10^{-3}$ & $3.39 \times 10^{-4}$ & $1.30 \times 10^{-6}$ & $7.50 \times 10^{-3}$ & $2.34 \times 10^{-2}$ \\
\hline & & Combustion & $2.87 \times 10^{0}$ & $7.90 \times 10^{-3}$ & $1.40 \times 10^{-3}$ & - & $3.74 \times 10^{-3}$ & - \\
\hline & & Total & $3.19 \times 10^{0}$ & $1.09 \times 10^{-2}$ & $1.74 \times 10^{-3}$ & $1.30 \times 10^{-6}$ & $1.12 \times 10^{-2}$ & $2.34 \times 10^{-2}$ \\
\hline \multirow{3}{*}{ Kerosene } & \multirow{3}{*}{$\ell$} & Production & $8.29 \times 10^{-2}$ & $1.86 \times 10^{-4}$ & $1.07 \times 10^{-5}$ & $2.61 \times 10^{-10}$ & $8.28 \times 10^{-6}$ & $2.18 \times 10^{-2}$ \\
\hline & & Combustion & $2.19 \times 10^{0}$ & $4.34 \times 10^{-3}$ & $7.63 \times 10^{-4}$ & - & $7.14 \times 10^{-3}$ & - \\
\hline & & Total & $2.27 \times 10^{0}$ & $4.53 \times 10^{-3}$ & $7.74 \times 10^{-4}$ & $2.61 \times 10^{-10}$ & $7.15 \times 10^{-3}$ & $2.18 \times 10^{-2}$ \\
\hline \multirow{3}{*}{ City gas } & \multirow{3}{*}{$\mathrm{m}^{3}$} & Production & $4.96 \times 10^{-1}$ & $2.77 \times 10^{-3}$ & $1.13 \times 10^{-4}$ & $4.24 \times 10^{-9}$ & $1.87 \times 10^{-2}$ & $2.16 \times 10^{-2}$ \\
\hline & & Combustion & $3.11 \times 10^{0}$ & $3.37 \times 10^{-3}$ & $6.23 \times 10^{-4}$ & - & $1.98 \times 10^{-4}$ & - \\
\hline & & Total & $3.61 \times 10^{0}$ & $6.14 \times 10^{-3}$ & $7.36 \times 10^{-4}$ & $4.24 \times 10^{-9}$ & $1.89 \times 10^{-2}$ & $2.16 \times 10^{-2}$ \\
\hline
\end{tabular}

The unit of environmental impact categories, "GWP" is the $\mathrm{kg}-\mathrm{CO}_{2 \mathrm{eq}} / \mathrm{FU}$; "AP" is the $\mathrm{kg}-\mathrm{SO}_{2 \mathrm{eq}} / \mathrm{FU}$; " $\mathrm{EP}$ " is the $\mathrm{kg}-\mathrm{PO}_{4}{ }^{3-}$ eq $/ \mathrm{FU}$; "ODP" is the $\mathrm{kg}-\mathrm{CFC}-11_{\mathrm{eq}} / \mathrm{FU}$; "POCP" is the $\mathrm{kg}-\mathrm{C}_{2} \mathrm{H}_{4 \mathrm{eq}} / \mathrm{FU}$; "ADP" is the $\mathrm{kg}-\mathrm{Sb}$ eq $/ \mathrm{FU}$. 
Here, $E I C_{i, j}$ is the environmental impact unit of environmental impact type (j) for the function unit of energy source ( $i$ ). $P E_{i, k}$ is the emissions of the impact substance $(k)$ for each function unit caused by the production of energy source (i). IF $F_{j, k}$ is the impact factor of impact substance $(k)$ for the environmental impact type $(j)$. $C E_{i, k}$ is the emissions of impact substance $(k)$ for each function unit caused by the combustion of energy source (i) [25].

\subsection{Development of Building Energy Consumption Unit Database}

In this study, the amount of energy consumed for each usage type is provided to perform operating stage environmental impact assessments on buildings designed by the BTEI. Previous studies have proposed managing the environmental performance of buildings by including the buildings' usage types as well as the occupants in a database, if they are apparent [26].

To this end, the report of the Korean Energy Census was used as basic data, and the energy consumption was predicted by dividing data into household and commercial sectors.

In addition, the basic unit of evaluation based on the total floor area was established using the total floor area data for residential and commercial areas provided by the Ministry of Land, Infrastructure, and Transport. Analysis was performed on the energy of buildings with limited building functions and usage types, in particular the energy consumption caused by the buildings' heating/cooling operation, and these data were developed in units [27].

Table 5 shows the data types used as basic data for understanding energy consumption here. Basic data were collected from the Korea Building Energy Integrated Management System for 1398 buildings in Seoul, including office (795), education (16), medical (25), research (15), recycling (29), neighborhood living (356), training (9), cultural (83), automotive (11), sports (12), storage (7), and tourism facilities (32). The basic data included information on the building structure, building floor area, heating/cooling style, energy sources, and energy consumption [28].

Table 5. Categories of basic data for constructing energy statistics.

\begin{tabular}{cc}
\hline Information & Data \\
\hline Energy & $\begin{array}{c}\text { Electricity, Heat, Kerosens, City Gas } \\
\text { Boiler and heat circulation pump, individual heating equipment, } \\
\text { central heat source and individual heating equipment thermal } \\
\text { production }\end{array}$ \\
\cline { 2 - 3 } Heating/Cooling Style & $\begin{array}{c}\text { Central cooling/heating source (refrigeration equipment, cooling } \\
\text { tower, cool water circulation pump) and cooling circulation } \\
\text { pump, individual cooling equipment (EHP, GHP, PAC, etc.) } \\
\text { Includes operational electricity consumption other than } \\
\text { cooling/heating production of central cooling/heating source } \\
\text { and individual cooling equipment }\end{array}$ \\
\hline Basic Information & Building floor area
\end{tabular}

The basic data were used to provide consumption statistics for each of the buildings' energy sources to enable the prediction of the energy consumption resulting from the buildings' floor area as designed by the user.

Energy statistics for each building usage type were used, as shown in Table 6, to assess the buildings' environmental impact in concrete terms and to consider their environmental impact during the design stage. 
Table 6. Energy statistics for each building use.

\begin{tabular}{cccccc}
\hline Classification & Information & $\begin{array}{c}\text { Electricity } \\
\left(\mathbf{K W h} / \mathbf{m}^{\mathbf{2}}\right)\end{array}$ & $\begin{array}{c}\text { Heat } \\
\left(\mathbf{G c a l} / \mathbf{m}^{\mathbf{2}}\right)\end{array}$ & $\begin{array}{c}\text { Kerosens } \\
\left(\ell / \mathbf{m}^{\mathbf{2}}\right)\end{array}$ & $\begin{array}{c}\text { City Gas } \\
\left(\mathbf{m}^{\mathbf{3}} / \mathbf{m}^{\mathbf{2}}\right)\end{array}$ \\
\hline \multirow{3}{*}{ Residential } & Detached house & $7.407 \times 10^{-2}$ & - & $5.533 \times 10^{-6}$ & $7.667 \times 10^{-6}$ \\
\cline { 2 - 6 } & Apartment & $2.856 \times 10^{-2}$ & $1.780 \times 10^{-2}$ & $4.368 \times 10^{-8}$ & $5.167 \times 10^{-6}$ \\
\cline { 2 - 6 } & Townhouse & $1.091 \times 10^{-1}$ & $9.561 \times 10^{-4}$ & $5.777 \times 10^{-7}$ & $2.477 \times 10^{-5}$ \\
\cline { 2 - 6 } Commercial & Multiplex housing & $4.315 \times 10^{-2}$ & - & $1.126 \times 10^{-7}$ & $9.813 \times 10^{-6}$ \\
\hline \multirow{2}{*}{ Retail business } & $4.699 \times 10^{-1}$ & $6.331 \times 10^{-4}$ & $5.757 \times 10^{-7}$ & $6.356 \times 10^{-6}$ \\
\cline { 2 - 6 } & Lodging business & $1.789 \times 10^{-1}$ & $3.160 \times 10^{-4}$ & $4.225 \times 10^{-7}$ & $7.601 \times 10^{-6}$ \\
\hline
\end{tabular}

The energy statistics were used to develop a unit factor per floor area. The system makes it possible to use the floor area information extracted from the BTEI, to predict energy consumption, and the environmental impact assessment database to assess the operation stage.

An example design was made to estimate the energy consumption for each building function within a fixed level of allowable error. Therefore, statistical values representing the unit distribution characteristics were used as mode values [29].

The units for 12 target building functions were compared, and the results showed that recycling facilities showed the biggest units, followed by storage facilities and sports facilities. Because these facilities have a fixed consumption demand, their energy saving potential was considered to be lower than other buildings. However, office, education, and medical facilities, which have long lifetimes and relatively high units, were considered to have higher energy saving potential than the others.

\section{Case Study}

\subsection{Outline}

According to ISO 21931-1, a building's life cycle stages can be divided into the production, construction, operating, and disposal stages as shown Figure 3. The BTEI system that was developed in this study targets the production and operating stages. Therefore, this study used scenarios for each stage, as shown in Figure 4, to perform life cycle environmental impact assessments [30,31].

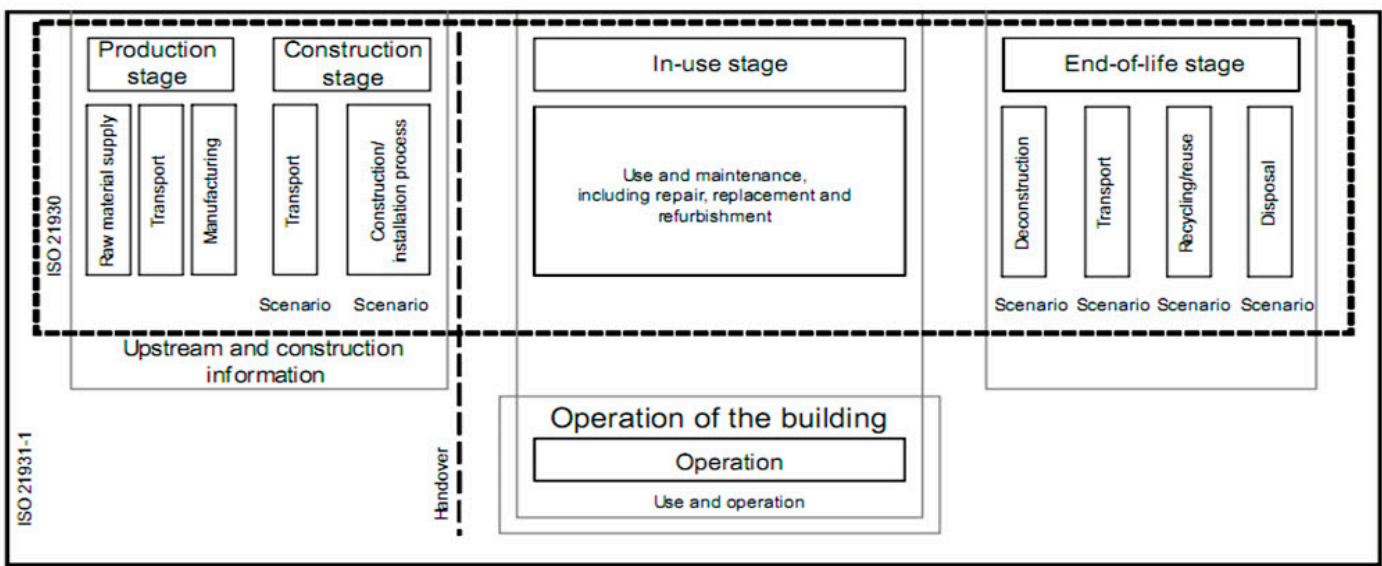

Figure 3. Life cycle assessment (LCA) scope according to ISO 21931-1. 


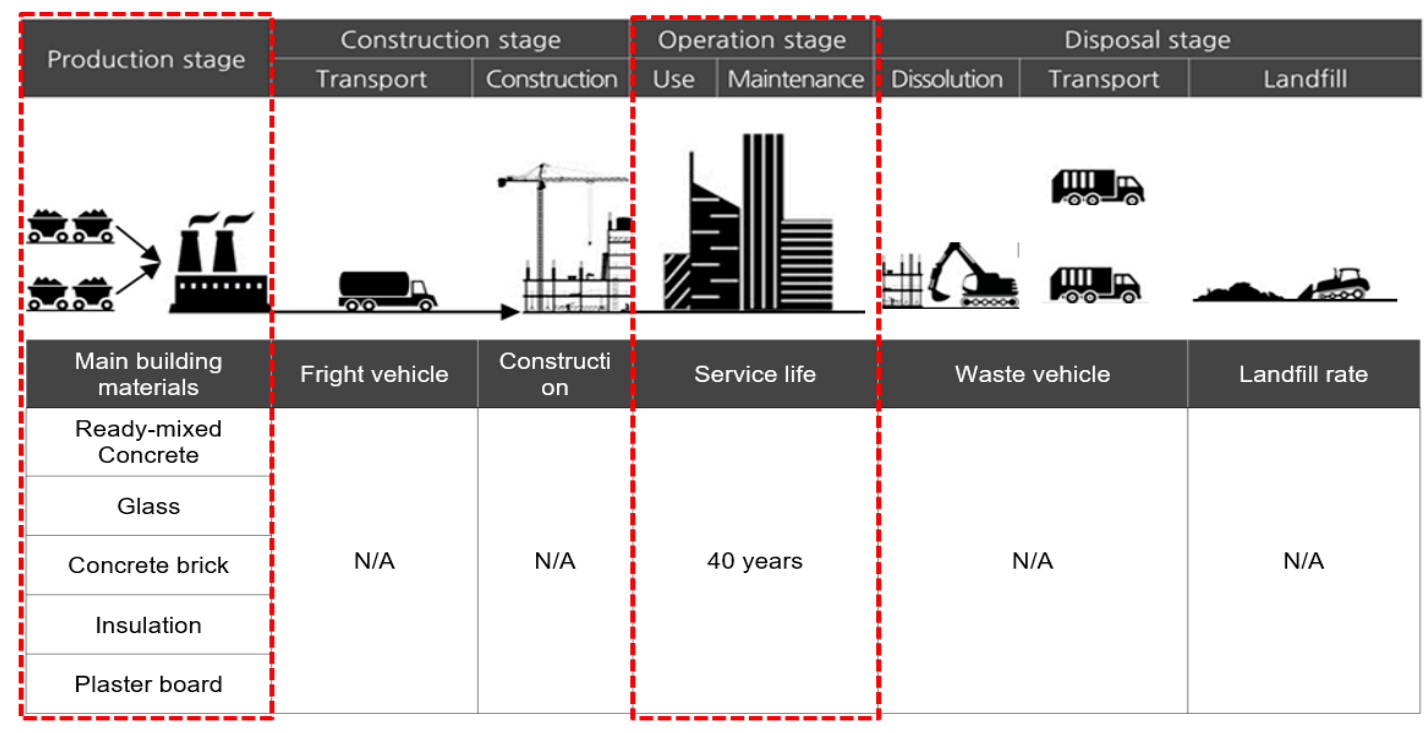

Figure 4. BTEI scenario by LCA stage.

This study calculated the major construction materials for the building production stage, which cause at least $95 \%$ of the major environmental impact types (GWP, AP, EP, ODP, POCP, and ADP) based on the environmental impact assessment results for buildings by previous studies.

This is because, in the production stage, construction materials account for at least $90 \%$ of the embodied environmental impact that occurs during the life cycle stages of the building [29].

In the production stage, the libraries provided by the BTEI environment were used and designed, and the embodied environmental impact during the buildings' life cycle stages was assessed [30].

To assess the environmental impact occurred in the operation stage, it is necessary to set the building's lifespan. The lifespan of a building could be subdivided based on its purpose and certain criteria in terms of its physical, functional, societal, economical, and legal lifespans. To assess the environmental impact of buildings in the initial stages of their construction and compare the assessment results, this study used a fixed lifespan of 40 years, which is stipulated by the Korean Corporate Tax Act for buildings [31].

\subsection{Assessment Method}

Verification was performed on the six environmental impact and environmental cost calculations, performed in BIM using the proposed BTEI system. In addition, the environmental impact caused by energy consumption was simulated using the operating stage environmental impact assessment database and energy statistics.

Environmental impact assessments were performed on the operation stages and the materials used in the actual building, as shown in Table 7. The assessment target was the, which is an apartment housing in Busan of South Korea. It is a residential building with 18 stories, made of reinforced concrete. Major construction materials with various characteristics were used in the building. 
Table 7. Overview of evaluation target.

\begin{tabular}{cc}
\hline & Information \\
\hline Project & An Apartment in Busan \\
\hline Purpose & Apartment \\
\hline Structural & Reinforced concrete \\
\hline Scale & 18 floors \\
\hline Life expectancy & 40 years \\
\hline Total ground areas & $5313.90 \mathrm{~m}^{2}$ \\
\hline Floor area & $282.95 \mathrm{~m}^{2}$ \\
\hline
\end{tabular}

27-MPa concrete was used from the 1st floor to the 7th floor, and 24-MPa concrete was used from the 8th floor to the 18th floor. Expanded polystyrene was used as the insulation, and double glazing glass and plate glass were used for the windows.

Environmental impact assessments were performed using the BTEI-based modeling and also with manual calculation, and the assessments were analyzed. First, the target building's actual calculation results were used to calculate the quantities of major construction materials such as concrete, glass, insulation, gypsum board, and bricks to directly assess the embodied environmental impact and environmental cost of each material.

Autodesk Revit Architecture 2015 was used to apply the BTEI, and modeling was performed on the assessment target at an LOD of 300. The BTEI modeled the concrete, bricks, glass, insulation, gypsum board, and concrete products and calculated the assessment results.

Modeling was performed using the BTEI library, which includes the environmental impact units, environmental cost units, and quantity unit conversion factor in the BIM task file. The BTEI-environmental impact assessment table function was used to display the results. Here, the unit conversion factor was a parameter needed to convert the volume unit quantities calculated in BIM to the standard units of the environmental impact units. Table 8 shows the unit conversion factor Weights were used for each construction material to calculate the unit conversion factor [32].

Table 8. Unit conversion factor.

\begin{tabular}{cccc}
\hline Major Materials & Revit S/W Unit & $\begin{array}{c}\text { 6 Environmental } \\
\text { Impacts Unit }\end{array}$ & $\begin{array}{c}\text { Unit Conversion } \\
\text { Factor }\end{array}$ \\
\hline Remicon & $\mathrm{m}^{3}$ & $\mathrm{~m}^{3}$ & 1 \\
\hline Plate Glass & $\mathrm{m}^{3}$ & ton & 0.0119 \\
\hline Double Glazing & $\mathrm{m}^{3}$ & $\mathrm{~m}^{2}$ & 200 \\
\hline Concrete Brick & $\mathrm{m}^{3}$ & 1000 ea & 0.75 \\
\hline Clay Brick & $\mathrm{m}^{3}$ & ton & 192 \\
\hline Insulation-Foam & $\mathrm{m}^{3}$ & ton & 0.03 \\
\hline Insulation-EPS & $\mathrm{m}^{3}$ & $\mathrm{~kg}$ & 0.16 \\
\hline Gypsum Board & $\mathrm{m}^{3}$ & ton & 0.863 \\
\hline
\end{tabular}

With regard to the operation stage, the environmental impact assessment results for 40 years, of the energy usage in the actual building and the building floor area that was modeled in the BTEI were used to analyze the assessment results that employed the operating stage environmental impact assessment units [33]. 


\subsection{Results of Environmental Impact Assessment on Major Building Materials}

\subsubsection{Environmental Impact Assessment Results}

A comparison of the assessment results was performed through a percentage analysis based on the manual calculation results, to compare the assessment results considering the six environmental impacts and environmental costs that were calculated using actual data and calculation by the BIM authoring tool (using the BTEI for each of the six environmental impact types).

Figure 5a shows the assessment results for each environmental impact type. In the BTEI, the overall results were similar to the actual calculation based assessment results, the error being just below $0.01 \%$. It was found that the error in acidification (AP), which had a $15 \%$ error compared to the ozone layer depletion (ODP) parameter, was caused by the type of insulation material used in the previously analyzed materials' environmental impact units. That is, it was found that the error was caused by using foam insulation, which was the only insulation library created in the BTEI, rather than using the expanded polystyrene that was used in the actual building. Figure $5 \mathrm{~b}$ demonstrates the material production stage environmental cost assessment results. In Figure $5 b$, there was a difference of approximately $4 \%$ between the BTEI's environmental cost assessment results and the actual calculation based assessment results. Table 9 shows the environmental impact and environmental cost assessment results for each material when using the supply calculation records and the BTEI on an apartment building. It was found that the BTEI assessment results were similar to those based on the supply calculation records for all six environmental impacts and environmental costs.

The global warming assessment results for concrete, which accounts for a large portion of the building's embodied environmental impact, exhibited an error rate of approximately $1.3 \%$, considering the environmental impact units for each strength (24 and $27 \mathrm{MPa})$.

It was determined that the BTEI results were similar to the actual supply calculation records because its libraries were constructed using environmental data that were subdivided for each construction material, confirming the significance of this study.

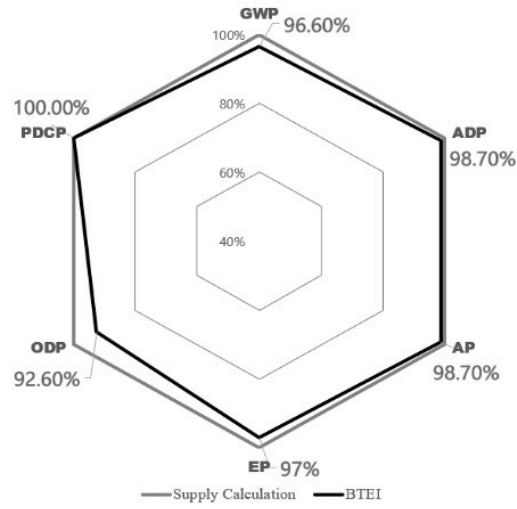

(a)

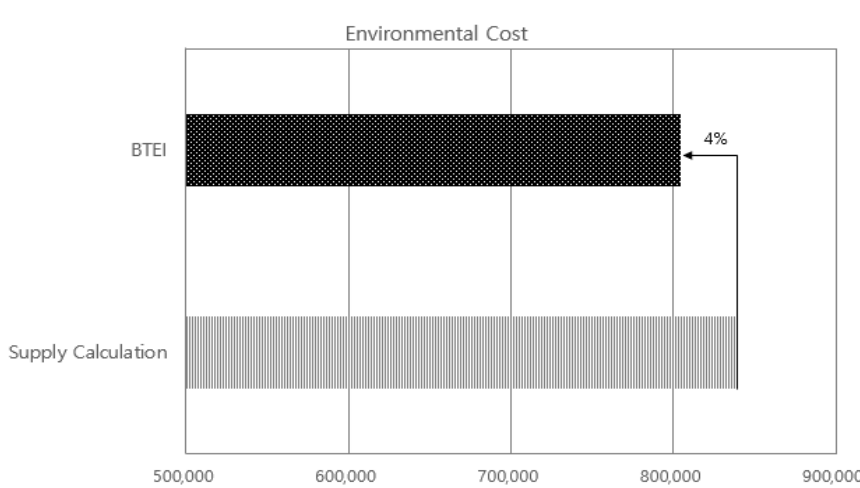

(b)

Figure 5. Analysis results. (a) Relative analysis of environmental impact between supply calculation and the BTEI. (b) Relative analysis of environmental cost between supply calculation and the BTEI. 
Table 9. Environmental impact and environmental cost for each major material.

\begin{tabular}{|c|c|c|c|c|c|c|c|c|}
\hline \multirow{2}{*}{ Category } & \multirow{2}{*}{ Material } & \multicolumn{6}{|c|}{6 Environmental Impact } & \multirow{2}{*}{$\begin{array}{c}\text { Environmental } \\
\text { Cost }\end{array}$} \\
\hline & & GWP & ADP & AP & EP & ODP & РОСР & \\
\hline \multirow{7}{*}{$\begin{array}{c}\text { BTEI } \\
\text { (BIM Template } \\
\text { for } \\
\text { Environmental } \\
\text { Impact } \\
\text { Evaluation) }\end{array}$} & Remicon $24 \mathrm{MPa}$ & $2.12 \times 10^{2}$ & $1.03 \times 10^{0}$ & $3.48 \times 10^{-1}$ & $4.04 \times 10^{-2}$ & $2.26 \times 10^{-5}$ & $5.67 \times 10^{-1}$ & $7.70 \times 10^{3}$ \\
\hline & Remicon $27 \mathrm{MPa}$ & $6.67 \times 10^{1}$ & $2.06 \times 10^{-1}$ & $1.03 \times 10^{-1}$ & $1.21 \times 10^{-2}$ & $7.31 \times 10^{-5}$ & $1.75 \times 10^{-1}$ & $2.34 \times 10^{3}$ \\
\hline & Plate Glass & $1.11 \times 10^{0}$ & $9.82 \times 10^{-3}$ & $5.17 \times 10^{-3}$ & $7.37 \times 10^{-5}$ & $4.28 \times 10^{-7}$ & $1.24 \times 10^{-3}$ & $7.88 \times 10^{1}$ \\
\hline & Double Glazing & $5.30 \times 10^{0}$ & $2.16 \times 10^{-2}$ & $7.22 \times 10^{-3}$ & $5.23 \times 10^{-4}$ & $4.23 \times 10^{-8}$ & $1.26 \times 10^{-2}$ & $1.68 \times 10^{2}$ \\
\hline & Concrete Brick & $2.02 \times 10^{1}$ & $2.40 \times 10^{-2}$ & $2.58 \times 10^{-2}$ & $3.73 \times 10^{-3}$ & $7.72 \times 10^{-7}$ & $2.13 \times 10^{-3}$ & $4.79 \times 10^{2}$ \\
\hline & EPS & $3.66 \times 10^{-2}$ & $2.58 \times 10^{-2}$ & $1.80 \times 10^{-1}$ & $4.77 \times 10^{-3}$ & $2.29 \times 10^{-2}$ & $2.14 \times 10^{-6}$ & $3.92 \times 10^{3}$ \\
\hline & Gypsum Board & $1.79 \times 10^{-1}$ & $1.45 \times 10^{-2}$ & $2.92 \times 10^{-2}$ & $4.93 \times 10^{-3}$ & $5.25 \times 10^{-7}$ & $7.09 \times 10^{-3}$ & $4.18 \times 10^{2}$ \\
\hline \multirow{7}{*}{$\begin{array}{c}\text { Supply } \\
\text { Calculation }\end{array}$} & Remicon $24 \mathrm{MPa}$ & $2.09 \times 10^{2}$ & $1.02 \times 10^{0}$ & $3.44 \times 10^{-1}$ & $4.00 \times 10^{-2}$ & $2.21 \times 10^{-5}$ & $5.61 \times 10^{-1}$ & $7.62 \times 10^{3}$ \\
\hline & Remicon $27 \mathrm{MPa}$ & $6.51 \times 10^{1}$ & $2.01 \times 10^{-1}$ & $1.01 \times 10^{-1}$ & $1.18 \times 10^{-2}$ & $7.12 \times 10^{-5}$ & $1.71 \times 10^{-1}$ & $2.28 \times 10^{3}$ \\
\hline & Plate Glass & $1.44 \times 10^{0}$ & $1.27 \times 10^{-2}$ & $6.70 \times 10^{-3}$ & $9.54 \times 10^{-5}$ & $5.52 \times 10^{-7}$ & $1.62 \times 10^{-3}$ & $1.02 \times 10^{2}$ \\
\hline & Double Glazing & $8.77 \times 10^{0}$ & $3.57 \times 10^{-2}$ & $1.19 \times 10^{-2}$ & $8.65 \times 10^{-4}$ & $7.02 \times 10^{-8}$ & $2.10 \times 10^{-2}$ & $2.77 \times 10^{2}$ \\
\hline & Concrete Brick & $3.09 \times 10^{-2}$ & $3.67 \times 10^{-2}$ & $3.95 \times 10^{-2}$ & $5.71 \times 10^{-3}$ & $1.12 \times 10^{-6}$ & $3.26 \times 10^{-3}$ & $7.33 \times 10^{2}$ \\
\hline & EPS & $3.95 \times 10^{-2}$ & $2.79 \times 10^{-2}$ & $1.94 \times 10^{-1}$ & $5.15 \times 10^{-3}$ & $3.12 \times 10^{-2}$ & $2.39 \times 10^{-6}$ & $4.24 \times 10^{3}$ \\
\hline & Gypsum Board & $1.82 \times 10^{-1}$ & $1.47 \times 10^{-2}$ & $2.96 \times 10^{-2}$ & $4.99 \times 10^{-3}$ & $5.24 \times 10^{-7}$ & $7.16 \times 10^{-3}$ & $4.23 \times 10^{2}$ \\
\hline
\end{tabular}

GWP (kg-CO $\mathrm{CO}_{2}$ /unit), ADP (kg/Unit), AP (kg-SO ${ }_{2}$ eq/Unit), EP (kg-PO ${ }_{4}{ }^{3-}$ eq/unit), ODP (kg-CFC-11eq/Unit), POCP (kgEthyleneeq/Unit), Environmental Cost (Won/ $\mathrm{m}^{2}$ ).

\subsubsection{Results of Environmental Impact Assessment on the Operation Stage}

In the BTEI Template, the operating stage environmental impact assessment database proposed in this study and the energy consumption statistical data for each building were added to the BTEI. The user could simulate the environmental impact caused by operating stage energy consumption using only a BIM design with an LOD 300.

This study compared and analyzed the environmental impact assessment results based on the case-study assessment target building's actual energy consumption and those calculated using the floor area of the target buildings as designed in the BTEI at an LOD 300. The assessment results are shown in Table 10.

Table 10. Operating stage environmental impact assessment results.

\begin{tabular}{|c|c|c|c|c|}
\hline \multicolumn{2}{|c|}{ Category } & \multirow{2}{*}{$\begin{array}{c}\text { Case Targeted Building } \\
60,108,040\end{array}$} & \multirow{2}{*}{$\begin{array}{c}\text { BTEI } \\
57,523,394\end{array}$} & \multirow[t]{2}{*}{ Difference Rate } \\
\hline Energy Use & Electricity use (Kwh) & & & \\
\hline \multirow{6}{*}{$\begin{array}{l}\text { Environmental } \\
\text { Impact }\end{array}$} & GWP (Kg-CO ${ }_{2}$ eq/unit) & $2.93 \times 10^{7}$ & $2.81 \times 10^{7}$ & \multirow{6}{*}{$4.3 \%$} \\
\hline & $\mathrm{ADP}(\mathrm{kg} /$ Unit $)$ & $5.03 \times 10^{4}$ & $4.81 \times 10^{4}$ & \\
\hline & $\mathrm{AP}\left(\mathrm{kg}-\mathrm{SO}_{2} \mathrm{eq} /\right.$ Unit $)$ & $9.38 \times 10^{3}$ & $8.97 \times 10^{3}$ & \\
\hline & $\mathrm{EP}\left(\mathrm{Kg}-\mathrm{PO}_{4}{ }^{3-}\right.$ eq/unit $)$ & $8.23 \times 10^{-4}$ & $7.88 \times 10^{-4}$ & \\
\hline & ODP (kg-CFC-11eq/Unit) & $8.48 \times 10^{1}$ & $8.11 \times 10^{1}$ & \\
\hline & PDCP (kg-Ethyleneeq/Unit) & $5.16 \times 10^{4}$ & $4.94 \times 10^{4}$ & \\
\hline
\end{tabular}

The building's life span was set to 40 years. For the case study, the actual average electricity consumption for the last five years was assumed for 40 years to calculate the assessment results. For the BTEI, the floor area-based energy consumption statistics were used to calculate the energy consumption, and the environmental impact assessment database was used to calculate the results. As shown in Table 10, there was a $4.3 \%$ difference between the BTEI assessment results and those based on the actual energy consumption, which confirms the significance of the proposed methodology.

\section{Discussion}

The purpose of this study was to create the BIM BTEI template, providing a method to assess the embodied environmental impact and operating stage environmental impact 
of buildings using the BIM authoring tool Revit as part of the development of assessment technologies for six categories of building environmental impacts.

A BIM template is a consistent input with a fixed, preset structure that is often used to obtain a calculated output suitable for certain assessment goals and scopes regarding the use of BIM modeling information [33].

Currently, studies on using BIM to assess the environmental performance of buildings are being conducted, but this approach is limited by the fact that the data lack of compatibility, no standard data, and the assessments can take too long [34,35].

With the BTEI approach, the expected results can be obtained rapidly using data that were previously provided by the user via templates. The BTEI provides major construction element libraries and tables for assessing the embodied environmental impacts of buildings in Revit. The major construction elements have been divided into walls, columns, slabs, and windows, and 46 libraries were created-the major construction materials that make up the elements being ready-mixed concrete, glass, concrete bricks, insulation, and gypsum board.

It is possible to simulate the operating stage energy consumption based on the building's designed floor area data and to use this to derive the six environmental impact assessment results.

The BTEI assesses the environmental impact of the material production stage and the building's operation stage, and it is possible to account for approximately $90 \%$ of the building's LCA. In addition, the system's biggest advantage is that various types of environmental performance can be considered without linking to other programs by using building information that can be extracted from the BIM system.

Construction materials such as rebars that cannot be considered in the Revit architecture may lower the reliability of the assessment results. Rebar is an element that must be considered in a building's embodied environmental impact assessment because it is a major construction material accounting for $20 \%$ or more of a building's embodied environmental impact. To improve the BTEI standards, it is necessary to allow rebar and premium rates for major construction materials to be considered for each building modeling LOD.

In this study, an assessment database was developed to consider the environmental impacts of the operation stage. However, it does not include various eco-friendly technologies and building materials which are currently being used to reduce the environmental impacts from the operation stage of buildings.

To improve the usefulness and reliability of the BTEI, it will be necessary to perform further studies that consider eight types of major building materials, including rebar and steel framing, rather than six types as well as studies that comprehensively assess the environmental impact of buildings that use specific materials and sustainable technologies to reduce environmental loads.

\section{Conclusions}

The goal of this study was to develop the BIM Template to evaluate the environmental impact of the building material production stage and operation stage using the Revit application, which is a BIM authoring tool, as part of research on the development of BIM-based building life cycle environmental impact assessment. The BIM template BTEI was developed, which made it possible to assess embodied and operational environmental impacts with environmental cost within a BIM authoring tool. When evaluating the sustainability of a building in the early stages of the construction project, the BIM Template developed in this study is very useful. If the accurate information on the input amount of building materials for an apartment house is insufficient, this research method is applied to evaluate the sustainability of the entire process of the building. This is because it is possible to make a comprehensive judgment. This study attempted to expand the area of analysis by incorporating the method of using BIM in the field of sustainability assessment throughout the entire building process. By presenting the environmental performance and economic evaluation method at the building design stage according to the characteristics of the building according to the characteristics of the building, the information on the 
input amount of building materials, which is a key area for the sustainability assessment at the initial stage of the building project, will be helpful in future studies on sustainability assessment throughout the entire building process. It is believed to be possible. In addition, 72 libraries including 6 categories of environmental impact and economics DB built in this study can be used as a systematic evaluation method of buildings, and furthermore, effectively support stakeholder decision-making to enhance the sustainability of the entire process. It is believed to be possible.

Author Contributions: Conceptualization, S.L., S.T. and H.J.; methodology, S.L. and S.T.; formal analysis, Y.B.; investigation, Y.B.; resources, S.L.; data curation, S.L. and Y.B.; writing-original draft preparation, S.L.; writing-review and editing, C.U.C.; visualization, S.L.; supervision, S.T.; funding acquisition, S.T. All authors have read and agreed to the published version of the manuscript.

Funding: This research was supported by Basic Science Research Program through the National Research Foundation of Korea (NRF) funded by the Ministry of Education, Science and Technology (No. 2018R1D1A1A09083678) and supported by the National Research Foundation of Korea (NRF) grant funded by the Korea government (MSIT) (No. 2015R1A5A1037548).

Institutional Review Board Statement: Not applicable.

Informed Consent Statement: Informed consent was obtained from all subjects involved in the study.

Data Availability Statement: Data sharing not applicable.

Conflicts of Interest: The authors declare no conflict of interest.

\section{References}

1. Cabeza, L.; Rincon, L.; Vilarinob, V.; Pereza, G.; Castell, A. Life cycle assessment (LCA) and life cycle energy analysis (LCEA) of buildings and the building sector: A review. Renew. Sustain. Energy Rev. 2014, 29, 394-416. [CrossRef]

2. Ministry of Land Infrastructure and Transport. Green Building Certification System in Korea; Ministry of Land Infrastructure and Transport: Sejong, Korea, 2013.

3. Roh, S.; Tae, S.; Shin, S. A Development of Building materials embodied greenhouse gases assessment criteria and system (BEGAS) in the newly revised Korea Green Building Certification System(G-SEED). Renew. Sustain. Energy Rev. 2014, 35, 410-421. [CrossRef]

4. Li, X.; Yang, F.; Zhu, Y.; Gao, Y. An assessment framework for analyzing the embodied carbon impacts of residential buildings in China. Energy Build. 2014, 85, 400-409. [CrossRef]

5. Seinre, E.; Kurnitski, J.; Voll, H. Building sustainability objective assessment in Estonian context and a comparative evaluation with LEED and BREEAM. Build. Environ. 2014, 82, 110-120. [CrossRef]

6. Alshamrani, O.S.; Galal, K.; Alkass, S. Integrated LCA-LEED sustainability assessment model for structure and envelope systems of school buildings. Build. Environ. 2014, 80, 61-70. [CrossRef]

7. ISO. ISO 14040: Environmental Management_Life Cycle Assessment_Principles and Framework; ISO: Geneva, Switzerland, 2006.

8. ISO. ISO 14025: Environmental Labels and Declarations-Type III Environmental Declarations_Principles and Procedures; ISO: Geneva, Switzerland, 2006.

9. ISO. ISO 14044: Environmental Management_Life Cycle Assessment_Requirements and Guidelines; ISO: Geneva, Switzerland, 2006.

10. Ministry of Environment, Korea Life Cycle Inventory Database. Korea Environmental Industry \& Technology Institute. Available online: http:/ / www.edp.or.kr/lci/lci_db.asp (accessed on 3 December 2020).

11. Ministry of Environment, Korea Environmental Industry \& Technology Institute. Development of Integrated Evaluation Technology on Product Value for Dissemination of Environmentally Preferable Products; Korea Ministry of Environment: Sejong, Korea, 2009.

12. Bang, J.; Tae, S.; Kim, T.; Roh, S. A Study on Developing BIM template based on Public Procurement Service Standard Construction Code to Improve the Efficiency in Carbon Dioxide Assessment of Buildings. Archit. Inst. Korea 2013, $29,69-76$.

13. Roh, S.; Tae, S.; Kim, R. Analysis of Embodied Environmental Impacts of Korean Apartment Buildings Considering Major Building Materials. Sustainability 2018, 10, 1693. [CrossRef]

14. Roh, S.; Tae, S.; Shin, S.; Woo, J. Development of an optimum design program (SUSB-OPTIMUM) for the life cycle CO2 assessment of an apartment house in Korea. Build Environ. 2014, 73, 40-54. [CrossRef]

15. Lee, S.; Tae, S.; Kim, T.; Roh, S. Development of Green Template for Building Life Cycle Assessment using BIM. J. Korea Spat. Inf. Soc. 2015, 23, 1-8.

16. Roh, S.; Tae, S.; Suk, S.; Ford, G.; Shin, S. Development of a building life cycle carbon emissions assessment program (BEGAS 2.0) for Korea's green building index certification system. Renew. Sustain. Energy Rev. 2016, 53, 954-965. [CrossRef]

17. Heinonen, J.; Säynäjoki, A.; Junnonen, J.; Pöyry, A.; Junnila, S. Pre-use phase LCA of a multi-story residential building: Can greenhouse gas emissions be used as a more general environmental performance indicator? Build. Environ. 2016, 95, 116-125. [CrossRef] 
18. Choi, J. A study on the Building Energy Evaluation Using Land Plus Mass Parameter Family of Building Information Modeling at the Early Design Stage. J. Archit. Inst. Korea 2013, 29, 273-280.

19. Fan, S.; Skibniewski, M.; Hung, T. Effects of building information modeling during construction. J. Appl. Sci. Eng. 2014, 17, 156-166.

20. Laprise, M.; Lufkin, S.; Rey, E. An indicator system for the assessment of sustainability integrated into the project dynamics of regeneration of disused urban areas. Build. Environ. 2015, 86, 29-38.

21. Kang, L.; Kwak, J. Integrated Code Classification System for work Sections in Standard Method of Measurement and Construction Standard Specification. Korea Inst. Constr. Eng. Manag. 2001, 4, 81-91.

22. Hunkeler, D. Societal LCA methodology and case study. Int. J. Life Cycle Assess 2006, 11, 371-382. [CrossRef]

23. Lee, S.; Tae, S. Development of a Decision Support Model Based on Machine Learning for Applying Greenhouse Gas Reduction Technology. Sustainability 2020, 12, 3582. [CrossRef]

24. Roh, S. Life Cycle Sustainability Assessment Model of Buildings using Probabilistic Analysis Method. Ph.D. Thesis, Hanyang University, Seoul, Korea, 2017.

25. Lee, S.; Tae, S. The Greenhouse Gas Evaluation Methodology of Energy End Use based on Big-Data. Int. J. Sustain. Build. Urban Dev. 2020, 78-93. [CrossRef]

26. Chae, M.S. Selection Model for Optimal Target Building for Green Remodeling Using Data-Mining Techniques: Focused on Multi-Family Housing Complex. Master's Thesis, Yonsei University, Seoul, Korea, 2017.

27. Ministry of Trade, Industry and Energy. Energy Consumption Survey; Ministry of Trade, Industry and Energy: Sejong, Korea, 2017.

28. Nakano, R.; Zusman, E.; Nugroho, S.; Kaswanto, R.; Arifin, N.; Munandar, A.; Arifin, H.S.; Muchtar, M.; Gomi, K.; Fujita, T. Determinants of energy savings in Indonesia: The case of LED lighting in Bogor. Sustain. Cities Soc. 2018, 42, 184-193. [CrossRef]

29. ISO. ISO 21931-1: Sustainability in Building Construction-Framework for Methods of Assessment of the Environmental Performance of Construction Works_-Part 1: Buildings; ISO: Geneva, Switzerland, 2010.

30. Korea Energy Agency. Guidance for Clean Development Mechanism; Korea Energy Agency: Ulsan, Korea, 2018.

31. Peng, J.; Lu, L.; Yang, H. Review on life cycle assessment of energy payback and greenhouse gas emission of solar photovoltaic systems. Renew. Sustain. Energy Rev. 2013, 19, 255-274. [CrossRef]

32. Korea Environment Preservation Association. Handbook for Environmental Labelling Certification; KEPA: Seoul, Korea, 2013.

33. Singh, D.; Basu, C.; Meinhardt-Wollweber, M.; Roth, B.W. LEDs for energy efficient greenhouse lighting. Renew. Sustain. Energy Rev. 2015, 49, 139-147. [CrossRef]

34. Ministry of Environment. Guidance for Greenhouse Gas Energy Target Management System; Ministry of Environment: Sejong, Korea, 2017.

35. Lacirignola, M.; Meany, B.H.; Padey, P.; Blanc, I. A simplified model for the estimation of life-cycle greenhouse gas emissions of enhanced geothermal systems. Geotherm. Energy 2014, 2, 1-19. [CrossRef] 